\title{
Microbial community response to ammonia levels in hydrogen assisted biogas
} production and upgrading process

\author{
Wang, Han; Zhu, Xinyu; Yan, Qun; Zhang, Yifeng; Angelidaki, Irini
}

Published in:

Bioresource Technology

Link to article, DOI:

10.1016/j.biortech.2019.122276

Publication date:

2020

Document Version

Peer reviewed version

Link back to DTU Orbit

Citation (APA):

Wang, H., Zhu, X., Yan, Q., Zhang, Y., \& Angelidaki, I. (2020). Microbial community response to ammonia levels in hydrogen assisted biogas production and upgrading process. Bioresource Technology, 296, [122276]. https://doi.org/10.1016/j.biortech.2019.122276

\section{General rights}

Copyright and moral rights for the publications made accessible in the public portal are retained by the authors and/or other copyright owners and it is a condition of accessing publications that users recognise and abide by the legal requirements associated with these rights.

- Users may download and print one copy of any publication from the public portal for the purpose of private study or research.

- You may not further distribute the material or use it for any profit-making activity or commercial gain

- You may freely distribute the URL identifying the publication in the public portal 


\section{Journal Pre-proofs}

Microbial community response to ammonia levels in hydrogen assisted biogas production and upgrading process

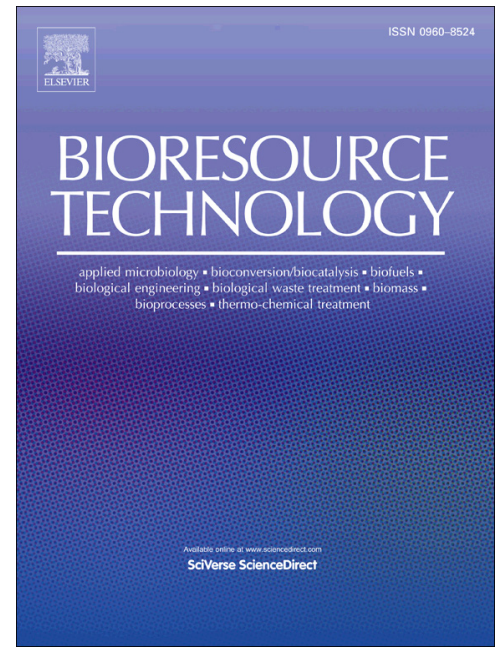

Han Wang, Xinyu Zhu, Qun Yan, Yifeng Zhang, Irini Angelidaki

PII: S0960-8524(19)31506-8

DOI: https://doi.org/10.1016/j.biortech.2019.122276

Reference: BITE 122276

To appear in: Bioresource Technology

Received Date: 6 September 2019

Revised Date: $\quad 7$ October 2019

Accepted Date: $\quad 15$ October 2019

Please cite this article as: Wang, H., Zhu, X., Yan, Q., Zhang, Y., Angelidaki, I., Microbial community response to ammonia levels in hydrogen assisted biogas production and upgrading process, Bioresource Technology (2019), doi: https://doi.org/10.1016/j.biortech.2019.122276

This is a PDF file of an article that has undergone enhancements after acceptance, such as the addition of a cover page and metadata, and formatting for readability, but it is not yet the definitive version of record. This version will undergo additional copyediting, typesetting and review before it is published in its final form, but we are providing this version to give early visibility of the article. Please note that, during the production process, errors may be discovered which could affect the content, and all legal disclaimers that apply to the journal pertain.

(C) 2019 Elsevier Ltd. All rights reserved. 
Microbial community response to ammonia levels in hydrogen assisted biogas production and upgrading process

Han Wang ${ }^{1,2}$, Xinyu Zhu ${ }^{2}$, Qun Yan ${ }^{1}$, Yifeng Zhang ${ }^{2 *}$, and Irini Angelidaki ${ }^{2}$

${ }^{1}$ School of Environmental and Civil Engineering, Jiangnan University, Wuxi, 214122,

China

${ }^{2}$ Department of Environmental Engineering, Technical University of Denmark, DK-2800 Kgs. Lyngby, Denmark

*Corresponding Author: Yifeng Zhang, e-mail address: yifz@env.dtu.dk 


\section{Abstract}

Biological conversion of carbon dioxide into methane using hydrogen derived from surplus renewable energy (wind power) as reducing power is a novel technology for biogas upgrading. High ammonia concentrations are toxic to the biogas upgrading process, however the mechanisms behind the inhibition as well as the microbial stress response in such unique upgrading system have never been reported. Thus, the effect of high ammonia concentrations on microbial community during hydrogen induced biogas upgrading process was evaluated here. The results showed that a change from aceticlastic pathway to hydrogenotrophic pathway occurred when ammonia level increased (1-7 $\left.\mathrm{g} \mathrm{NH}_{4}{ }^{+}-\mathrm{N} \mathrm{L}^{-1}\right)$. In addition, the bacteria, potentially syntrophic associated with hydrogenotrophic methanogens, were enriched at high ammonia concentrations. Moreover, growth of some bacteria (e.g., Halanaerobiaceaeen and Leucobacter) which were vulnerable to ammonia toxicity was restored upon hydrogen injection. Furthermore, hydrogen injection under high ammonia concentration could promote growth of some hydrolytic and fermentative bacteria.

Keywords: Anaerobic digestion; Biogas upgrading; Microbial community; Ammonia inhibition; Hydrogenotrophic methanogens 


\section{Introduction}

Anaerobic digestion $(A D)$ is one of the most widely used technologies that can treat various organic wastewaters and slurries to reduce the organic load and obtain renewable energy at the same time. Generally, the AD process can be described as a four steps process: hydrolysis, acidogenesis, acetogenesis and methanogenesis. In each step, specific groups of microorganisms take corresponding roles. In specific, hydrolysis is an enzymatic process and bacteria participate in acidogenesis and acetogenesis, while several groups of archaea are involved in methanogenesis, which is considered to be sensitive to unfavorable conditions (Angelidaki et al, 2011). There are two main pathways in methanogenesis step, the aceticlastic and hydrogenotrophic pathways. In the aceticlastic pathway, acetate is consumed by aceticlastic methanogens (i.e. Methanosarcinaceae spp. and Methanosaetaceae spp.) to produce methane. Acetate on the other hand, can be converted to methane through an alternative indirect pathway, involving the collaboration of syntrophic acetate oxidation bacteria (SAOB) and hydrogenotrophic methanogens. Firstly, SAOB can consume acetate to produce hydrogen and carbon dioxide. Secondly, hydrogen and carbon dioxide generated in the first step are converted to methane by hydrogenotrophic methanogens (i.e. Methanococcales spp., Methanobacteriales spp. and Methanomicrobiales spp.).

Although organic wastes can be treated with advantage by anaerobic digestion, there are challenges which need to be addressed. A major challenge is often ammonia inhibition. Ammonia $\left(\mathrm{NH}_{4}{ }^{+} / \mathrm{NH}_{3}\right)$ is considered as the major toxic inhibitor that causes instability of AD process and further reduction of biogas production (Chen et al., 2008; 
Yenigün \& Demirel, 2013). $\mathrm{NH}_{3}$ molecules can diffuse passively into the microbes' cells, resulting in proton imbalance, potassium deficiency, changing intracellular $\mathrm{pH}$ and suppressing specific enzymatic reactions (Gallert et al., 1998; Wang et al., 2015). Efforts have been previously made to understand the effect of high ammonia levels on the methanogenic pathways shift and the methanogenic community changes. It was reported that hydrogenotrophic methanogens are more resistant to high ammonia concentrations compared with aceticlastic methanogens (Wang et al., 2016; Angelidaki \& Ahring, 1993). On the contrary, a significant shift from hydrogenotrophic pathway to aceticlastic pathway was observed upon the increase of ammonia levels (1-5 $\mathrm{g} \mathrm{NH}_{4}{ }^{+}-\mathrm{N}$ $\mathrm{L}^{-1}$ ) at thermophilic condition (Fotidis et al., 2013). However, there was no pathway shift observed at mesophilic condition. In the same study, the increase of ammonia levels also resulted in the reduction of archaea diversity from three dominant methanogenic species (Methanosarcinaceae spp., Methanobacteriales spp. and Methanomicrobiales spp.) to one (Methanosarcinaceae spp.) in mesophilic condition. In addition, Calli et al (2005) reported that the dominant methanogens changed from Methanosaeta-related species to Methanosarcina-related species with the increase of free ammonia concentration (from 161 to $750 \mathrm{mg} \mathrm{NH}_{3}-\mathrm{N} \mathrm{L}^{-1}$ ), together with significant increase of hydrogenotrophic methanogens (i.e. Methanospirillium and Methanobacterium-related species). This was related to the increased acetate concentration, which was a result of the high ammonia levels. That shows that the observed effects are a result of interconnected parameters as a reaction to increased ammonia load. Overall, there is still unclarity and contradictory reports of the effect of high ammonia levels on methanogenic community and further studies are required. 
Recently, a novel biological biogas upgrading process, which consumes carbon dioxide in biogas and hydrogen derived from surplus renewable energy sources (e.g., wind power) to produce methane, has been reported (Luo et al., 2012 ; Luo \& Angelidaki, 2012). For this novel biogas upgrading process, the effects of hydrogen on the microbial community have been well studied. Specifically, after hydrogen injection to anaerobic reactors, an obvious growth of the relative abundance of archaea community was detected and Methanoculleus was observed as dominant genus. The hydrogenotrophic pathway was improved during the biogas upgrading process by the growth of syntrophic Desulfovibrio and hydrogenotrophic methanogens with the reduction of aceticlastic methanogens (Bassani et al., 2015). On the contrary, the effect of ammonia on the key anaerobic microorganisms during the biological biogas upgrading process is still unclear. Considering that ammonia inhibition is one of the most common problems in $A D$, we have studied the effect of ammonia concentrations on microbial community during hydrogen assisted biological biogas upgrading process at both mesophilic and thermophilic conditions. The results could reveal the microbial community response to high ammonia concentrations and offer insights into alleviating ammonia inhibition during the biogas upgrading process.

\section{Materials and methods}

\subsection{Inoculum and feedstock}

The inoculums used were taken from Hashøj and Snertinge Biogas Plants, which were operating at mesophilic and thermophilic temperatures respectively. The substrate used by both full-scale biogas reactors is a mixture of organic wastes from food industries $(10-30 \% \mathrm{w} / \mathrm{w})$ and cattle manure $(70-90 \% \mathrm{w} / \mathrm{w})$. The ammonia levels of the 
mesophilic and thermophilic reactors were 3.46 and $3.01 \mathrm{~g} \mathrm{NH}_{4}{ }^{+}-\mathrm{N} \cdot \mathrm{L}^{-1}$, respectively. Moreover, the cattle manure applied in the experiments, was taken from Hash øj biogas plant. The pretreatment procedure of the cattle manure and the basic characteristics of the substrate and inoculum can be found in a previous study (Wang et al., 2016).

\subsection{Experimental setup}

It has been reported that the inhibition of $A D$ process occurred at $4 \mathrm{~g} \mathrm{NH}_{4}^{+}-\mathrm{N} \mathrm{L}^{-1}$ in batch experiments (Sung and Liu, 2003). Therefore, 1 and $7 \mathrm{~g} \mathrm{NH}_{4}^{+}-\mathrm{N} \mathrm{L}^{-1}$ were used to represent the ammonia levels that resulted in no inhibition at all and serious inhibition, respectively. $\mathrm{NH}_{4} \mathrm{Cl}$ was applied as ammonia source for both mesophilic and thermophilic cultivation. The total volume of batch reactors was $118 \mathrm{~mL}$, in which 40 $\mathrm{mL}$ was working volume. Inoculum $(10 \mathrm{~mL})$, cattle manure $(10 \mathrm{~mL})$ and distilled water $(20 \mathrm{~mL})$ were added into batch reactors. Afterwards, the batch reactors were sealed with butyl rubber stoppers and aluminum crimps. Nitrogen was used as purge gas to create anaerobic condition in the batch reactors. Subsequently, 0, 19.5, 39 and $78 \mathrm{~mL}$ of hydrogen were added into batch reactors to get different hydrogen partial pressure $(0,0.25,0.5$, and $1 \mathrm{~atm})$ under $7 \mathrm{~g} \mathrm{NH}_{4}{ }^{+}-\mathrm{N} \mathrm{L}^{-1}$ (Table 1). Mesophilic and thermophilic batch reactors were put into corresponding shaking incubators $\left(180 \mathrm{rpm}, 37^{\circ} \mathrm{C}\right.$ and $\left.55^{\circ} \mathrm{C}\right)$ for cultivation.

The total solids (TS), volatile solids (VS) and total ammonia nitrogen were determined on the basis of APHA's Standard Methods (Federation \& Association, 2005). Moreover, the determination methods of methane production and biogas composition in batch reactors were described in a previous study (Wang et al., 2016). 


\subsection{Calculation}

The free ammonia concentrations were obtained according to the following equation (Wang et al., 2015):

$\mathrm{FAN}=\frac{\mathrm{TAN}}{1+\frac{10^{-\mathrm{pH}}}{K_{a}}}$

Where TAN is total ammonia nitrogen, $K_{a}$ is a dissociation constant $\left(1.29 \times 10^{-9}\right.$ for $37^{\circ} \mathrm{C}$ and $3.91 \times 10^{-9}$ for $55^{\circ} \mathrm{C}$ ) and $\mathrm{pH}$ is equal to the initial $\mathrm{pH}$ as shown in Table 1.

\subsection{DNA extraction and sequencing}

Sludge samples were retrieved from all batch reactors at the end of the cultivation period. Genomic DNA of the sludge samples was isolated with PowerSoil ${ }^{\circledR}$ DNA Isolation Kit (MoBio PowerSoil, Carlsbad, CA USA) through extra phenol cleaning steps. The specific procedure of cleaning could be found in a previous study (Zhu et al., 2017). Moreover, the bacterial and archaeal universal primer (515f/806r) was used for amplifying the V4 regions of $16 \mathrm{~S}$ ribosomal RNA gene by PCR (Klindworth et al., 2012). Furthermore, sequencing of the amplicons was completed with llumina Meseq platform (Ramaciotti Centre for Genomics, Kensington, Australia).

\subsection{Data analysis}

For processing the raw sequences, CLC Workbench software (V.8.0.2) with microbial genomics module was applied. The low quality reads were trimmed by default parameters set in the software. Operational taxonomic units were created using $97 \%$ similarity and when the similarity of taxonomy was less than $80 \%$ (at least 5 reads), 
new OTUs creation was permitted. By applying Greengenes v13_5 database (clustered at $97 \%)$, Multiple Sequence Comparison was completed on fixed length trimmed (240bp) sequences with Log-Expectation for fulfilling OUTs phylogenetic assignment. According to the number of OTUs, Chao 1 bias-corrected and Phylogenetic diversity and Bray-Curtis matrix, Alpha and Beta Diversity (Principal Coordinates Analysis (PCoA)) were both determined, respectively. The top $90 \%$ of abundant taxa were selected with a self-written R script. PCoA was performed with Bray-Curtis distance indices and visualized with classical multidimensional scaling function in vegan packages. The statistical tests for sample comparison were performed with statistical analysis of metagenomics profiles (STAMP v2.1.2). Raw data can be found in the database of Sequence Read Archive (SRA) (http://www.ncbi.nlm.nih.gov/sra) under the IDs: PRJNA552564.

\section{Results and discussion}

\subsection{Overall performance}

As can be seen in Table 2, a significant reduction of methane yield $(p<0.05)$ was observed at $7 \mathrm{~g} \mathrm{NH}_{4}{ }^{+}-\mathrm{N} \mathrm{L}^{-1}$ compared with $1 \mathrm{~g} \mathrm{NH}_{4}{ }^{+}-\mathrm{N} \mathrm{L}^{-1}$ (from 253.5 to $88.8 \mathrm{ml} \mathrm{CH}_{4}$ (g VS) ${ }^{-1}$ for mesophilic; from 239.8 to $133.8 \mathrm{ml} \mathrm{CH}_{4}$ (g VS) ${ }^{-1}$ for thermophilic), which indicated that high ammonia concentration could cause serious ammonia inhibition in both mesophilic and thermophilic conditions. However, when hydrogen was injected $(0.25,0.5$ and $1 \mathrm{~atm})$, the methane yields were higher compared to batch reactors without hydrogen added under $7 \mathrm{~g} \mathrm{NH}_{4}^{+}-\mathrm{N} \mathrm{L}^{-1}$ in both mesophilic and thermophilic conditions. In the present study, the theoretical methane production from the injected hydrogen was subtracted. Therefore, the results indicated that hydrogen injection 
could improve the tolerance of batch reactors to ammonia toxicity. In addition, it should be noted that the methane yield of thermophilic reactor was higher compared with mesophilic condition under $7 \mathrm{~g} \mathrm{NH}_{4}{ }^{+}-\mathrm{N} \mathrm{L}^{-1}(0,0.25,0.5$ and $1 \mathrm{~atm})$, even though the free ammonia concentration in the thermophilic reactor was $174.2 \mathrm{mg} \mathrm{NH}_{3} \mathrm{~L}^{-1}$ higher than that in mesophilic reactor (Table 1). The results were contrary to some previous studies which have suggested that thermophilic methanogenesis are more sensitive to ammonia toxicity compared to mesophilic ones due to the higher free ammonia levels (Angelidaki and Ahring, 1994; Chen et al., 2008). However, Luo \& Angelidaki (2012) reported that thermophilic hydrogenotrophic methanogens are more efficient than mesophilic ones for methane yield after hydrogen injection owing to the higher digestion rates at thermophilic condition. It is still possible for thermophilic methanogenesis being more resistant to free ammonia, which could be also explained by the evolution of thermophilic methanogenesis to improve resistance to high free ammonia concentrations.

Carbon dioxide contents of biogas were shown in Table 2. In mesophilic reactors, the carbon dioxide content was reduced with hydrogen injection under $7 \mathrm{~g} \mathrm{NH}_{4}^{+}-\mathrm{N} \mathrm{L}^{-1}$. The lowest carbon dioxide content was achieved when hydrogen partial pressure was 0.5 atm. Similar results were also detected in thermophilic condition with hydrogen injection and the lowest carbon dioxide content was obtained with $1 \mathrm{~atm}$ of hydrogen partial pressure. In detail, under $7 \mathrm{~g} \mathrm{NH}_{4}{ }^{+}-\mathrm{N} \mathrm{L}^{-1}$ the carbon dioxide contents in batch reactors without hydrogen injection decreased by $15.7 \%$, while the $\mathrm{CO}_{2}$ content decreased by $21.2 \%$ in reactors with hydrogen addition (mesophilic $0.5 \mathrm{~atm}$ and thermophilic $1 \mathrm{~atm})$, as hydrogen has reacted with carbon dioxide to generate 
methane. These results indicated that the hydrogen assisted biogas upgrading process could still be achieved under high ammonia levels.

\subsection{Overall microbial diversity of sludge samples}

The Beta diversity of the microbial community obtained under different experimental conditions was evaluated with Bray-Curtis dissimilarity matrix and visualized using PCoA (Figure 1). There was a considerable distance between the samples under 1 and $7 \mathrm{~g} \mathrm{NH}_{4}{ }^{+}-\mathrm{N} \mathrm{L}^{-1}$ at mesophilic condition, indicating the increase of ammonia concentration led to significant changes in microbial community composition. On the other hand, microbial composition was relatively similar at thermophilic condition under different ammonia levels. This could be due to the lower microbial diversity at thermophilic temperatures, which did not permit large variations despite the different ammonia loads. In the present study it was obvious that the thermophilic culture used in the experiments was more ammonia tolerant compared to the mesophilic culture used. Moreover, the increase of ammonia concentration and addition of hydrogen both drove the shift of mesophilic microbial community to thermophilic-like composition. The detailed information of microbial community at different experimental conditions is further discussed in the following sections.

\subsection{The effect of high ammonia concentration on bacterial community changes}

Bacterial community changes with increasing ammonia concentrations (without hydrogen injection) in mesophilic and thermophilic conditions were shown in Figure 2. OTUs belonging to phyla Actinobacteria, Bacteroidetes, Firmicutes, Proteobacteria and Chloroflexi, which play critical roles during AD process (Lin et al., 2016) were the dominants in all samples. In mesophilic condition OTUs belonging to Corynebacterium 
(Actinobacteria), Sedimentibacter (Firmicutes) and Anaerolineae (Chloroflexi) decreased sharply in relative abundance $(p<0.05)$ when ammonia concentrations increased from 1 to $7 \mathrm{~g} \mathrm{NH}_{4}^{+}-\mathrm{N} \mathrm{L}^{-1}$. The results indicated that Corynebacterium, Sedimentibacter and Anaerolineae were vulnerable to high ammonia levels. Corynebacterium are considered as facultatively anaerobic or aerobic bacteria and can generate various organic acids from carbohydrates (Bernard et al., 2010). Moreover, Sedimentibacter are reported to be crucial in the degradation process of the volatile fatty acids accumulated during AD process (Regueiro et al., 2014). Anaerolineae, belonging to the family of Anaerolineaceae, could cooperate with hydrogenotrophic methanogens (St-Pierre and Wright, 2014) and play important role in the biogas production process (Palatsi et al., 2011). Therefore, the decrease of these bacteria's relative abundances could cause the inhibition of $A D$ process under $7 \mathrm{~g} \mathrm{NH}_{4}^{+}-\mathrm{N} \mathrm{L}^{-1}$. Meanwhile, in genus (or family) level, the abundances of Porphyromonas (Bacteroidetes), Syntrophomonas (Firmicutes), Thermoanaerobacteraceae (Firmicutes) and Clostridium (Firmicutes) increased more than 21 folds with the increasing of ammonia level. Members of genera Syntrophomonas and Clostridium, known as fattyacid degrading bacteria syntrophically associating with hydrogenotrophic methanogens, were enriched under high ammonia concentrations in the present study. Similar results are reported in a previous study (Schnürer et al., 2008). Moreover, Thermoanaerobacteraceae members were also likely involved in the collaboration of syntrophic acetate oxidation and hydrogenotrophic methanogens when aceticlastic methanogenesis were not active (Bassani et al., 2015). In another previous study, Thermoanaerobacteraceae was reported to convert format and 
acetate to hydrogen containing end products (ethanol and carbon dioxide) (Win et al., 2016). Overall, all the changes in bacterial composition suggested a promotion of hydrogen producing activity under high ammonia levels, which can be associated with the methanogenic pathway shift from acetoclastic to hydrogenotrophic. In addition, Porphyromonas belonged to the family of Porphyromonadaceae, which was involved in the process of protein and carbohydrates degradation and generation of different kinds of organic acids (Hahnke et al., 2015).

With the increasing ammonia levels at thermophilic condition, only 6 OTUs have effective size of difference higher than 1\% (Figure 2), which was agreed with the results shown in Figure 1. The less shift of thermophilic microbial community is probably due to the low microbial diversity. Apparently, the few OTUs present at thermophilic conditions were more resistant to ammonia loads as well to hydrogen injection. This could indicate that the lower the diversity in a mixed culture the lower the margins for microbial composition shifts. Moreover, besides the same dominate bacteria detected as in mesophilic condition (Porphyromonas and Clostridium), there were also genus (or family) of Pseudomonas (Proteobacteria) and Erysipelotrichaceae (Firmicutes) presented (Figure 2). Specifically, Pseudomonas might be involved in the production of hydrolytic enzymes and also connected with microthermal fermentation in thermophilic reactors (Tsapekos et al., 2017). In addition, Erysipelotrichaceae could acidify glucose or other sugars and may be related to the digestion of protein (Ziganshina et al., 2015). 


\subsection{The effect of hydrogen injection on bacterial community under high ammonia concentration}

Under high ammonia concentration $\left(7 \mathrm{~g} \mathrm{NH}_{4}{ }^{+}-\mathrm{N} \mathrm{L}^{-1}\right)$, the hydrogen injection led to nearly 2 folds of increase for Thermoanaerobacteraceae, Ruminococcaceae and Clostridium (Figure 3). Specifically, the increase of Thermoanaerobacteraceae and Clostridium members was consistent with the changes introduced by high ammonia levels. These results indicated that adding hydrogen in the reactor led to a more robust microbial community composition which can resist higher ammonia concentrations compared with traditional AD process. Moreover, Ruminococcaceae played important role in the hydrolysis process of complex carbohydrates (Ecem et al., 2018). The results demonstrated that the hydrogen assisted biogas production and upgrading process might also benefit hydrolysis and acidogenesis steps during $A D$ process under high ammonia levels.

At thermophilic condition, there were genera (or families) of Halanaerobiaceaeen (Firmicutes), Porphyromonadaceae (Bacteroidetes), Planococcaceae (Firmicutes) and Leucobacter (Actinobacteria) enriched by hydrogen injection under high ammonia concentration $\left(7 \mathrm{~g} \mathrm{NH}_{4}{ }^{+}-\mathrm{N} \mathrm{L}^{-1}\right)$ which were not present at mesophilic condition (Figure 3). In detail, it has been reported that Halanaerobiaceaeen has the ability to ferment cellulose and glucose (Tang et al., 2011). Moreover, Planococcaceae are known as fermentative or hydrolytic bacteria (Gao et al., 2012). In addition, it should be noted that similarly to the mesophilic condition Ruminococcaceae family was also present at thermophilic condition, but at lower abundance indicating its preference to lower temperatures. This result was in agreement with a previous study in which the 
abundances of Ruminococcaceae family increased immediately after decreasing temperature to mesophilic condition (Madigou et al., 2019).

\subsection{The changes of archaeal community}

When ammonia levels increased (1-7 $\mathrm{g} \mathrm{NH}_{4}{ }^{+}-\mathrm{N} \mathrm{L}^{-1}$, without hydrogen injection), a significant reduction $(\mathrm{p}<0.05)$ of microbial community for Methanosaeta and Methanobacteriales was detected in mesophilic batch reactor (Figure 4). Oppositely, the abundances of Methanothermobacter thermautotrophicus and Methanobacterium increased more than 20 folds and became dominant, which indicated a change from aceticlastic to hydrogenotrophic pathway. This result was in line with the fact that hydrogenotrophic methanogens are more resistant to high ammonia levels than aceticlastic methanogens (Wang et al., 2016). Besides Methanobacterium, the relative abundances of Methanosarcina and Methanobrevibacter increased with the changing of ammonia levels from 1 to $7 \mathrm{~g} \mathrm{NH}_{4}{ }^{+}-\mathrm{N} \mathrm{L}^{-1}$ at thermophilic condition. Methanosarcina has been reported to be resistant to high ammonia levels (more than $7 \mathrm{~g} \mathrm{NH}_{4}{ }^{+}-\mathrm{N} \mathrm{L}^{-1}$ ) (Yan et al., 2019). Its unique capability could be attributed to the large spherical shape which supplies more volume to surface ratio and thereby impeding ammonia diffusion into microbial cells (Zeb et al., 2019). Moreover, when VFA accumulation and pH decrease occurred due to the ammonia inhibition, Methanosarcina members are favored owing to their excellent growth rate under high VFA concentrations and their ability to alleviate pH shock (Venkiteshwaran et al., 2015). As a hydrogenotrophic methanogen, Methanobrevibacter was also found to be resistant to high ammonia concentrations in previous study (Bayrakdar et al., 2017), which was in accordance with the results of the present study. 
Under mesophilic conditions, the abundances of hydrogenotrophic methanogens Methanothermobacter thermautotrophicus and Methanobrevibacter increased 0.5 and more than 30 folds with the raising of hydrogen partial pressure from 0 to 0.5 atm under high ammonia concentration $\left(7 \mathrm{~g} \mathrm{NH}_{4}{ }^{+}-\mathrm{N} \mathrm{L}^{-1}\right)$ respectively (Figure 4), confirmed that hydrogenotrophic methanogens were enriched during the hydrogen assisted biogas production and upgrading process. The results were consistent with the increased methane yield and low carbon dioxide content (Table 2). It should be also noted that the abundances of Methanosarcina decreased sharply with hydrogen injection under high ammonia concentration $\left(7 \mathrm{~g} \mathrm{NH}_{4}{ }^{+}-\mathrm{N} \mathrm{L}^{-1}\right)$. Although Methanosarcina could perform both aceticlastic and hydrogenotrophic methanogenic pathway to produce methane, it has been reported that Methanosarcina favored aceticlastic methanogenesis under high ammonia levels (Yang et al., 2019). The result confirmed that hydrogenotrophic pathway could replace aceticlastic methanogenic pathway during the hydrogen assisted biogas production and upgrading process. Moreover, higher abundances of archaea OTUs in thermophilic condition were detected compared with mesophilic (E-supplementary data of this work can be found in online version of the paper), which was in accordance with the higher methane yield achieved in thermophilic reactors (Table 2).

Overall, various genus of archaea and bacteria were found to be tolerant to high ammonia levels and the abundances of some genus of archaea and bacteria were indeed improved in the reactors with hydrogen injection. For instance, both ammoniatolerant archaea (Methanothermobacter thermautotrophicus and Methanobrevibacter) and bacteria (Thermoanaerobacteraceae, Ruminococcaceae and 
Clostridium) were further improved by adding hydrogen into reactors. It should also be noted that the growth of some ammonia vulnerable bacteria (e.g., Halanaerobiaceaeen and Leucobacter) were enhanced by hydrogen injection. The enhanced growth of hydrogenotrophic methanogens was attributed to the hydrogen injection which further stimulated the metabolisms of SAOBs, since hydrogenotrophic methanogens could consume the products of SAOBs and overcome the energy barriers (Stams et al., 2009). In a previous study, Bassani et al (2015) reported that a hydrogen assisted biogas upgrading process can result in the increase of syntrophic bacteria and hydrogenotrophic methanogens and the reduction of hydrolytic and fermentative bacteria. However, the present study indicated that hydrogen injection under high ammonia concentration might also strengthen the growth of some hydrolytic and fermentative bacteria. The present study revealed the changes of microbial community under upon varied ammonia concentration and hydrogen partial pressures. The results could be helpful to fill the knowledge gap for biogas production and biological upgrading applications under high ammonia concentrations.

\section{Conclusions}

The present study investigated the response of microbial community to ammonia levels in hydrogen assisted biogas production and upgrading process. Higher abundances of archaea OTUs in thermophilic condition were detected compared to mesophilic condition. Moreover, a change of pathway from aceticlastic to hydrogenotrophic occurred under high ammonia level during hydrogen assisted biogas upgrading process. Bacteria sensitive to high ammonia levels could tolerate higher ammonia levels when hydrogen is added. In addition, the present study indicated that 
hydrogen injection under high ammonia concentration might also strengthen the growth of some hydrolytic and fermentative bacteria.

\section{Acknowledgements}

The authors would like to acknowledge financial support from The Danish Council for Independent Research (DFF-1335-00142) and Novo Nordisk Foundation (NNF160C0021568).

\section{References}

1. Angelidaki, I., Karakashev, D., Batstone, D.J., Plugge, C.M., Stams, A.J., 2011. Biomethanation and its potential. Methods Enzymol, 494, 327-351.

2. Angelidaki, I., Ahring, B., 1993. Thermophilic anaerobic digestion of livestock waste: the effect of ammonia. Applied Microbiology and Biotechnology, 38, $560-564$.

3. Angelidaki, I., Ahring, B., 1994. Anaerobic thermophilic digestion of manure at different ammonia loads: effect of temperature. Water Res, 28, 727-731.

4. Bassani, I., Kougias, P. G., Treu, L., Angelidaki, I., 2015. Biogas upgrading via hydrogenotrophic methanogenesis in two-stage continuous stirred tank reactors at mesophilic and thermophilic conditions. Environmental Science \& Technology, 49, 12585-12593.

5. Bayrakdar, A., Recep Önder Sürmeli., Baris Çalli., 2017. Dry anaerobic digestion of chicken manure coupled with membrane separation of ammonia. Bioresource Technol, 244, 816-823.

6. Bernard, K.A., Wiebe, D., Burdz, T., Reimer, A., Ng, B., Singh, C., Schindle, S., Pacheco, A.L., 2010. Assignment of Brevibacterium stationis (ZoBell and Upham 1944) Breed 1953 to the genus Corynebacterium, as Corynebacterium 
stationis comb. nov., and emended description of the genus Corynebacterium to include isolates that can alkalinize citrate. Int. J. Syst. Evol. Microbiol, 60, 874-879.

7. Calli, B., Mertoglu, B., Inanc, B., Yenigun, O., 2005. Methanogenic diversity in anaerobic bioreactors under extremely high ammonia levels. Enzyme \& Microbial Technology, 37, 448-455.

8. Chen, Y., Cheng, J., Creamer, S., 2008. Inhibition of anaerobic digestion process: a review. Bioresource Technol, 99, 4044-4064.

9. Ecem, B., Akyol, C., Bozan, M., Ince, O., Aydin, S., Ince, B., 2017.

Bioaugmentation with, clostridium thermocellum, to enhance the anaerobic biodegradation of lignocellulosic agricultural residues. Bioresource Technol, S096085241731859X.

10. Federation, W.E., Association, 2005. A.P.H. Standard methods for the examination of water and wastewater. American Public Health Association (APHA): Washington, DC, USA.

11. Fotidis, I.A., Karakashev, D., Kotsopoulos, T.A., Martzopoulos, G.G., Angelidaki, I., 2013. Effect of ammonium and acetate on methanogenic pathway and methanogenic community composition. FEMS Microbiology Ecology, 83, $38-48$.

12. Gallert, C., Bauer, S., Winter, J., 1998. Effect of ammonia on the anaerobic degradation of protein by a mesophilic and thermophilic biowaste population. Applied Microbiology and Biotechnology, 50, 495-501.

13. Gao, R., Yuan, X., Li, J., Wang, X., Cheng, X., Zhu, W., Cui, Z., 2012. Performance and spatial succession of a full-scale anaerobic plant treating high- 
concentration cassava bioethanol wastewater. Journal of Microbiology and Biotechnology, 22(8), 1148-1154.

14. Hahnke, S., Maus, I., Wibberg, D., Tomazetto, G., Puhler, A., Klocke, M., Schluter, A., 2015. Complete genome sequence of the novel Porphyromonadaceae bacterium strain ING2-E5B isolated from a mesophilic lab-scale biogas reactor. J. Biotechnol, 193, 34-36.

15. Klindworth, A., Pruesse, E., Schweer, T., Peplies, J., Quast, C., Horn, M., 2012. Evaluation of general 16s ribosomal rna gene pcr primers for classical and nextgeneration sequencing-based diversity studies. Nucleic Acids Research, 41, e1.

16. Lin, Q., He, G., Rui, J., Fang, X., Tao, Y., Li, J., 2016. Microorganismregulated mechanisms of temperature effects on the performance of anaerobic digestion. Microbial Cell Factories, 15, 1-18.

17. Luo, G., Angelidaki, I., 2012. Integrated biogas upgrading and hydrogen utilization in an anaerobic reactor containing enriched hydrogenotrophic methanogenic culture. Biotechnology and Bioengineering, 109, 2729-2736.

18. Luo, G., Johansson, S., Boe, K., Xie, L., Zhou, Q., Angelidaki, I., 2012. Simultaneous hydrogen utilization and in situ biogas upgrading in an anaerobic reactor. Biotechnology and Bioengineering, 109, 1088-1094.

19. Madigou, C., Cao, K., Bureau, C., Mazéas, L., Déjean, S., Chapleur, O., 2019. Ecological consequences of abrupt temperature changes in anaerobic digesters. Chemical Engineering Journal 361, 266-277.

20. Palatsi, J., Viñas, M., Guivernau, M., Fernandez, B., Flotats, X., 2011. Anaerobic digestion of slaughterhouse waste: main process limitations and microbial community interactions. Bioresour. Technol. 102, 2219-2227. 
21. Regueiro, L., Carballa, M., Lema, M., 2014. "Outlining microbial community dynamics during temperature drop and subsequent recovery period in anaerobic co-digestion systems." Journal of Biotechnology 192, 179-186.

22. Schnürer, A., Nordberg, A. 2008. Ammonia, a selective agent for methane production by syntrophic acetate oxidation at mesophilic temperature. Water Science \& Technology, 57, 735-740.

23. Stams, M., Plugge, M., 2009. Electron transfer in syntrophic communities of anaerobic bacteria and archaea. Nat. Rev. Microbiol. 7 (8), 568-577.

24. St-Pierre, B., Wright, G., 2014. Comparative metagenomic analysis of bacterial populations in three full-scale mesophilic anaerobic manure digesters. Appl. Microbiol. Biot. 98, 2709-2717.

25. Sung, S., Liu, T., 2003. Ammonia inhibition on thermophilic anaerobic digestion. Chemosphere, 53, 43-52.

26. Tang, Q., Ji, P., Hayashi, J., Koike, Y., Wu, L., Kida, K., 2011. Characteristic microbial community of a dry thermophilic methanogenic digester: its long-term stability and change with feeding. Applied Microbiology and Biotechnology, 91(5), 1447-1461.

27. Tsapekos, P., Kougias, P. G., Treu, L., Campanaro, S., Angelidaki, I., 2017. Process performance and comparative metagenomic analysis during codigestion of manure and lignocellulosic biomass for biogas production. Applied Energy, 185, 126-135.

28. Venkiteshwaran, K., Bocher, B., Maki, J., Zitomer, D., 2015. Relating anaerobic digestion microbial community and process function. Microbiol. Insights, 8 (S2), $37 e 43$. 
29. Wang, H., Fotidis, I., Angelidaki, I., 2015. Ammonia effect on hydrogenotrophic methanogens and syntrophic acetate oxidizing bacteria. FEMS Microbiology Ecology, 91(11).

30. Wang, H., Fotidis, I., Angelidaki, I., 2016. Ammonia-LCFA synergetic coinhibition effect in manure-based continuous biomethanation process.

Bioresource Technol, 209, 282-289.

31. Wang, H., Zhang, Y., Angelidaki, I., 2016. Ammonia inhibition on hydrogen enriched anaerobic digestion of manure under mesophilic and thermophilic conditions. Water Research, 105, 314-319.

32. Win, T., Kim, H., Cho, K., Song, G., Park, J., 2016. Monitoring the microbial community shift throughout the shock changes of hydraulic retention time in an anaerobic moving bed membrane bioreactor. Bioresource Technology, 202, $125-132$.

33. Yan, M., Fotidis, I., Tian, H., Khoshnevisan, B., Treu, L., Tsapekos, P., Angelidaki, I. 2019. Acclimatization contributes to stable anaerobic digestion of organic fraction of municipal solid waste under extreme ammonia levels: Focusing on microbial community dynamics. Bioresource Technol 286, 121376.

34. Yang, Z., Wang, W., Liu, C., Zhang, R., Liu, G., 2019. Mitigation of ammonia inhibition through bioaugmentation with different microorganisms during anaerobic digestion: Selection of strains and reactor performance evaluation. Water Research. 155, 214-224.

35. Yenigün, O., Demirel, B., 2013. Ammonia inhibition in anaerobic digestion: a review. Process Biochem, 48, 901-911. 
36. Zeb, I., Ma, J., Mehboob, F., Kafle, K. G., Amin, Z. B., Nazir, R., Ndegwa, P., Frear, C., 2019, Kinetic and microbial analysis of methane production from dairy wastewater anaerobic digester under ammonia and salinity stresses. Journal of Cleaner Production, 219, 797-808.

37. Ziganshina, E., Belostotskiy, E., Ilinskaya, N., Boulygina, A., Grigoryeva, V., Ziganshin, M., 2015. Effect of the Organic Loading Rate Increase and the Presence of Zeolite on Microbial Community Composition and Process Stability During Anaerobic Digestion of Chicken Wastes[J]. Microbial Ecology, 70(4), 948-960.

38. Zhu, X., Kougias, P. G., Treu, L., Campanaro, S., Angelidaki, I., 2017. Microbial community changes in methanogenic granules during the transition from mesophilic to thermophilic conditions. Applied Microbiology $\&$

Biotechnology, 101, 1-10. 


\section{Caption of Figures}

Figure 1. Beta diversity with Bray-Curtis dissimilarity (M: Mesophilic condition; T: Thermophilic condition; 1 and $7 \mathrm{~g}: 1$ and $7 \mathrm{~g} \mathrm{NH}_{4}{ }^{+}-\mathrm{N} \mathrm{L}^{-1} ; 0,0.25,0.5$ and 1: 0, 0.25, 0.5 and 1 atm of hydrogen partial pressure).

Figure 2. Changed OTUs after increasing ammonia levels both in mesophilic and thermophilic conditions (Pink background: difference more than 1\%; yellow background: difference less than $1 \%$ ).

Figure 3. Heat maps of bacterial profile under different hydrogen partial pressure both in mesophilic and thermophilic reactors.

Figure 4. Relative abundance of OTUs in archaeal community under different ammonia levels and hydrogen partial pressure. 


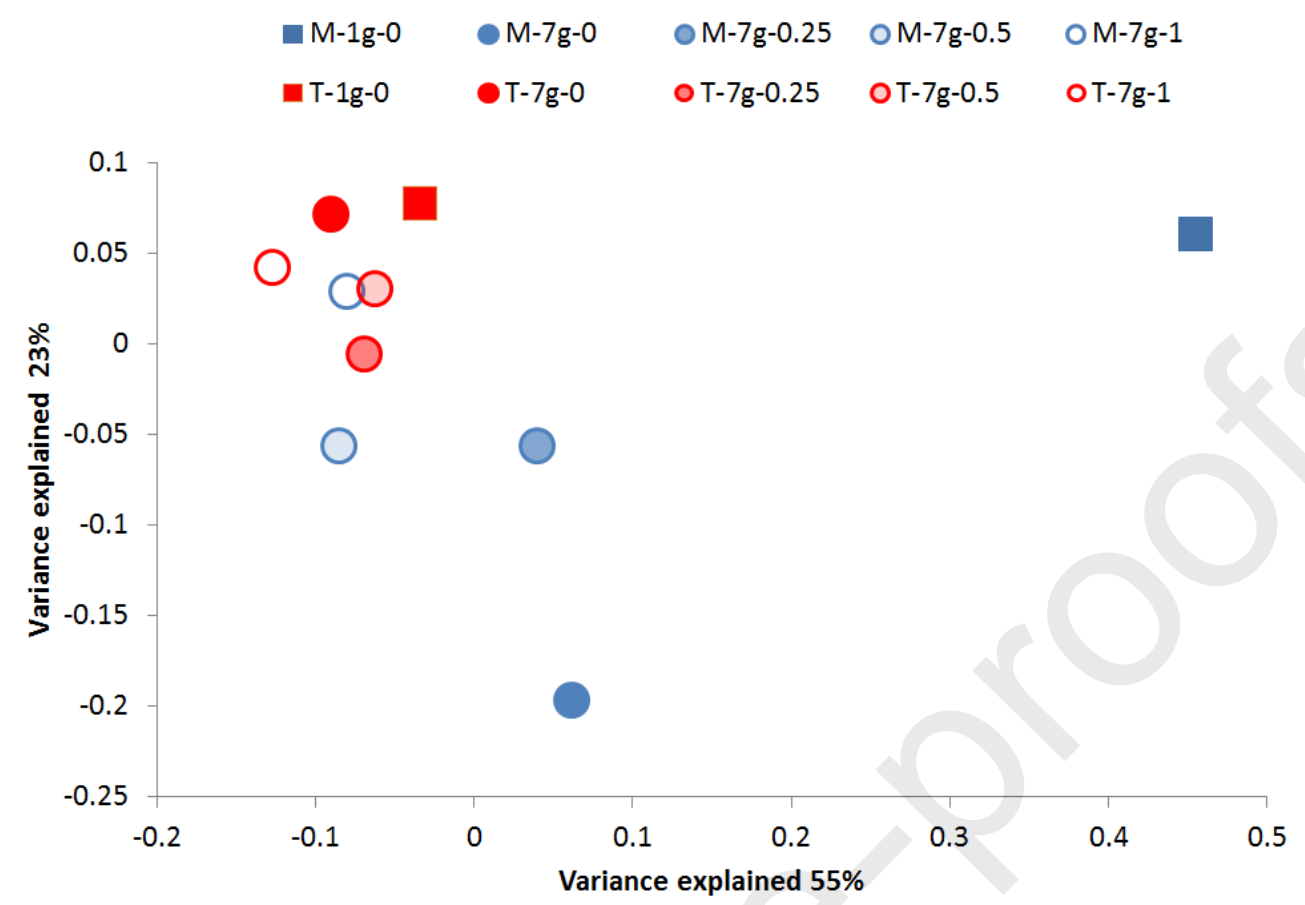

Figure 1. Beta diversity with Bray-Curtis dissimilarity (M: Mesophilic condition;

T: Thermophilic condition; 1 and $7 \mathrm{~g}: 1$ and $7 \mathrm{~g} \mathrm{NH}_{4}{ }^{+}-\mathrm{N} \mathrm{L}^{-1} ; 0,0.25,0.5$ and 1: 0 , $0.25,0.5$ and $1 \mathrm{~atm}$ of hydrogen partial pressure). 


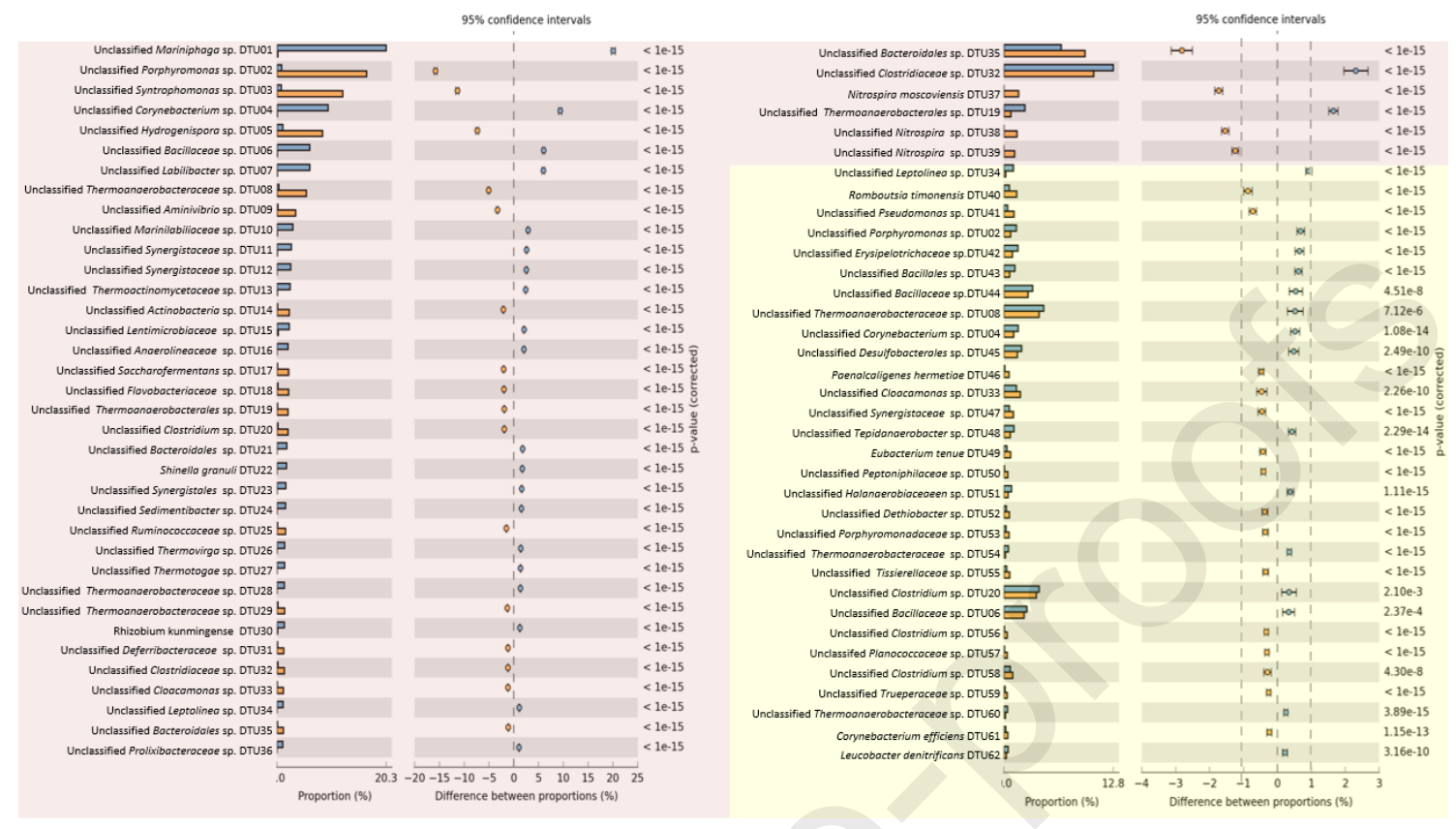

Figure 2. Changed OTUs after increasing ammonia levels both in mesophilic and thermophilic conditions (Pink background: difference more than 1\%; yellow background: difference less than $1 \%$ ). 

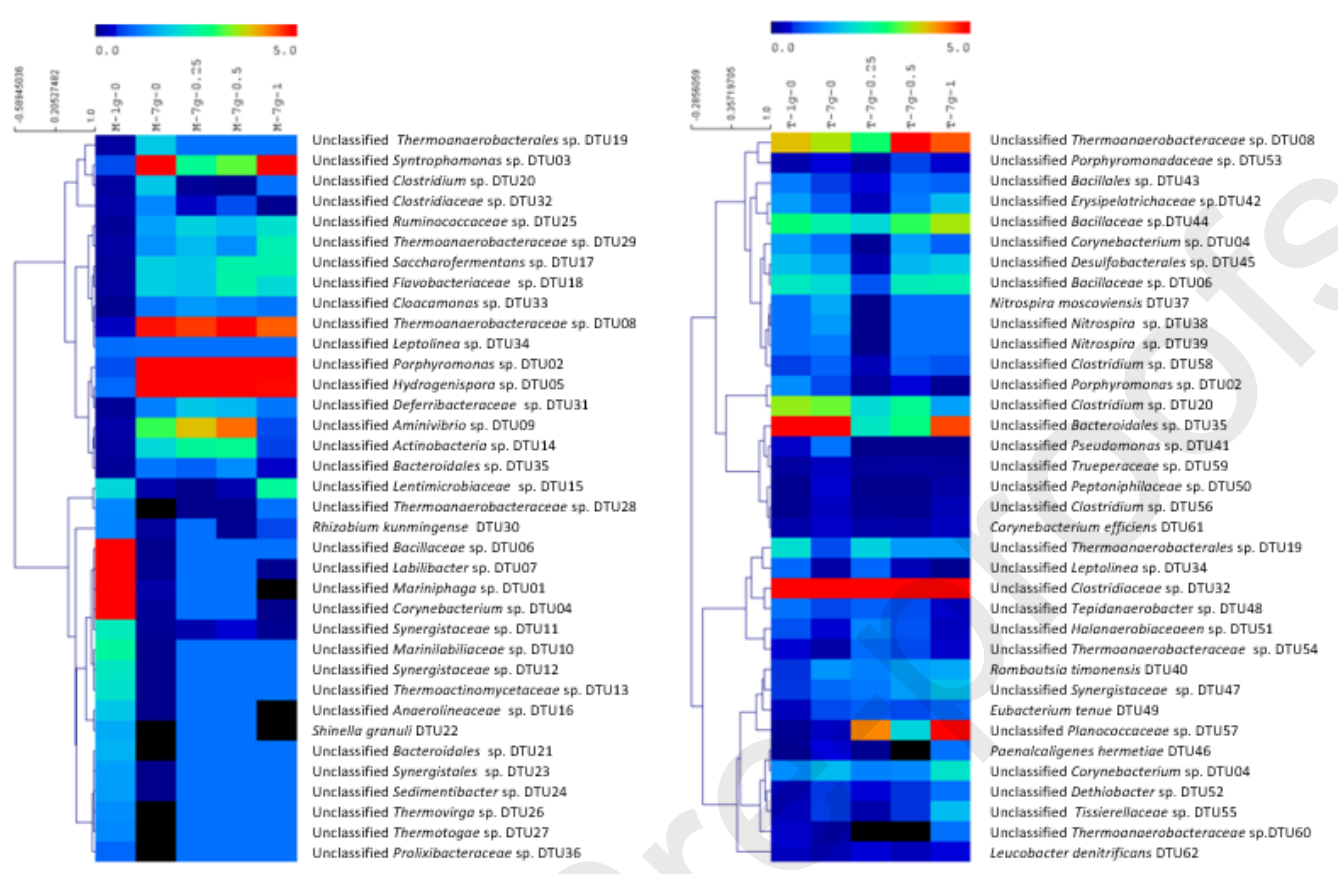

Figure 3. Heat maps of bacterial profile under different hydrogen partial pressure both in mesophilic and thermophilic reactors. 


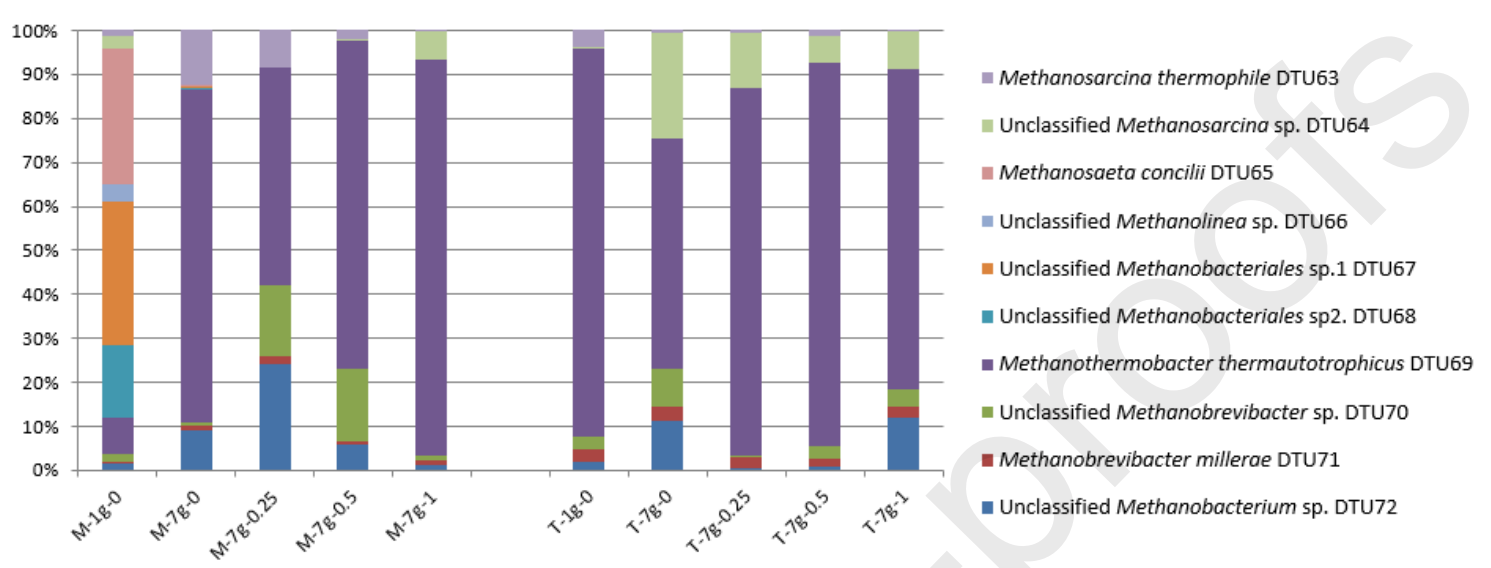

Figure 4. Relative abundance of OTUs in archaeal community under different ammonia levels and hydrogen partial pressure. 


\section{Caption of Tables}

Table 1. Batch reactors under different ammonia levels and hydrogen partial pressure.

Table 2. Methane yield, VFA concentrations and carbon dioxide contents of batch reactors under different ammonia levels and hydrogen partial pressure (the theoretical methane production from the injected hydrogen was subtracted). 
Table 1. Batch reactors under different ammonia levels and hydrogen partial pressure.

\begin{tabular}{|c|c|c|c|c|}
\hline & $0 \mathrm{~atm}$ & $0.25 \mathrm{~atm}$ & $0.5 \mathrm{~atm}$ & $1 \mathrm{~atm}$ \\
\hline $\begin{array}{l}\text { Mesophilic batch } \\
\text { reactors }\end{array}$ & $1 \& 7 \mathrm{~g} \mathrm{NH}_{4}{ }^{+}-\mathrm{N} \mathrm{L}^{-1}$ & $7 \mathrm{~g} \mathrm{NH}_{4}^{+}-\mathrm{N} \mathrm{L}^{-1}$ & $7 \mathrm{~g} \mathrm{NH}_{4}^{+}-\mathrm{N} \mathrm{L}^{-1}$ & $7 \mathrm{~g} \mathrm{NH}_{4}^{+}-\mathrm{N} \mathrm{L}^{-1}$ \\
\hline $\begin{array}{l}\text { Initial pH level of } \\
\text { mesophilic }\end{array}$ & $8.01 \& 7.95$ & 7.95 & 7.95 & 7.95 \\
\hline $\begin{array}{c}\text { Free ammonia of } \\
\text { mesophilic }\end{array}$ & $\begin{array}{c}12.70 \& 89.20 \mathrm{mg} \\
\mathrm{NH}_{3} \mathrm{~L}^{-1}\end{array}$ & $89.20 \mathrm{mg} \mathrm{NH}_{3} \mathrm{~L}^{-1}$ & $89.20 \mathrm{mg} \mathrm{NH}_{3} \mathrm{~L}^{-1}$ & $89.20 \mathrm{mg} \mathrm{NH}_{3} \mathrm{~L}^{-1}$ \\
\hline $\begin{array}{l}\text { Thermophilic } \\
\text { batch reactors }\end{array}$ & $1 \& 7 \mathrm{~g} \mathrm{NH}_{4}{ }^{+}-\mathrm{N} \mathrm{L}^{-1}$ & $7 \mathrm{~g} \mathrm{NH}_{4}^{+}-\mathrm{N} \mathrm{L}^{-1}$ & $7 \mathrm{~g} \mathrm{NH}_{4}^{+}-\mathrm{N} \mathrm{L}^{-1}$ & $7 \mathrm{~g} \mathrm{NH}_{4}^{+}-\mathrm{N} \mathrm{L}^{-1}$ \\
\hline $\begin{array}{l}\text { Initial pH level of } \\
\text { thermophilic }\end{array}$ & $8.05 \& 7.97$ & 7.97 & 7.97 & 7.97 \\
\hline $\begin{array}{l}\text { Free ammonia of } \\
\text { thermophilic }\end{array}$ & $\begin{array}{c}37.60 \& 263.40 \mathrm{mg} \\
\mathrm{NH}_{3} \mathrm{~L}^{-1}\end{array}$ & $263.40 \mathrm{mg} \mathrm{NH}_{3} \mathrm{~L}^{-1}$ & $263.40 \mathrm{mg} \mathrm{NH}_{3} \mathrm{~L}^{-1}$ & $263.40 \mathrm{mg} \mathrm{NH}_{3} \mathrm{~L}^{-1}$ \\
\hline
\end{tabular}


Table 2. Methane yield, VFA concentrations and carbon dioxide contents of batch reactors under different ammonia levels and hydrogen partial pressure (the theoretical methane production from the injected hydrogen was subtracted).

\begin{tabular}{|c|c|c|c|c|c|}
\hline & \multicolumn{2}{|l|}{$1 \mathrm{NH}_{4}^{+}-\mathrm{N} \mathrm{L}^{-1}$} & \multicolumn{2}{|c|}{$7 \mathrm{NH}_{4}^{+}-\mathrm{N} \mathrm{L}^{-}$} & \multirow[b]{2}{*}{$1 \mathrm{~atm}$} \\
\hline & $0 \mathrm{~atm}$ & 0 atm & $0.25 \mathrm{~atm}$ & $0.5 \mathrm{~atm}$ & \\
\hline \multicolumn{6}{|l|}{ Mesophilic } \\
\hline Methane yield (ml & $253.5 \pm 2.5$ & $88.8 \pm 3.8$ & $163.4 \pm 0.8$ & $181.0 \pm 4.2$ & $153.8 \pm 0.1$ \\
\hline \multicolumn{6}{|l|}{$\mathrm{CH}_{4}\left(\mathrm{~g} \mathrm{VS}^{-1}\right)$} \\
\hline $\begin{array}{c}\text { Mesophilic } \mathrm{CO}_{2} \\
\text { contents (\%) }\end{array}$ & $29.7 \pm 0.6$ & $38.1 \pm 0.4$ & $29.9 \pm 0.3$ & $22.4 \pm 0.9$ & $23.0 \pm 1.4$ \\
\hline Thermophilic & & & & & \\
\hline Methane yield (ml & $239.8 \pm 8.5$ & $133.8 \pm 10.6$ & $202.9 \pm 0.4$ & $229.5 \pm 0.3$ & $209.6 \pm 7.3$ \\
\hline $\mathrm{CH}_{4}\left(\mathrm{~g} \mathrm{VS}^{-1}\right)$ & & & & & \\
\hline $\begin{array}{c}\text { Thermophilic } \\
\mathrm{CO}_{2} \text { contents }(\%)\end{array}$ & $30.5 \pm 0.4$ & $40.0 \pm 0.2$ & $28.6 \pm 0.2$ & $25.0 \pm 0.6$ & $19.8 \pm 0.5$ \\
\hline
\end{tabular}




\section{Highlights}

- A change to hydrogenotrophic pathway occurred when ammonia increased.

- Bacteria which were vulnerable to ammonia could be restored by hydrogen injection.

- Both archaea and bacteria's tolerance to ammonia were improved by adding hydrogen.

- Higher abundances of archaea OTUs in thermophilic condition were detected. 


\section{Declaration of interests}

$\bigotimes$ The authors declare that they have no known competing financial interests or personal relationships that could have appeared to influence the work reported in this paper.

$\square$ The authors declare the following financial interests/personal relationships which may be considered as potential competing interests: 


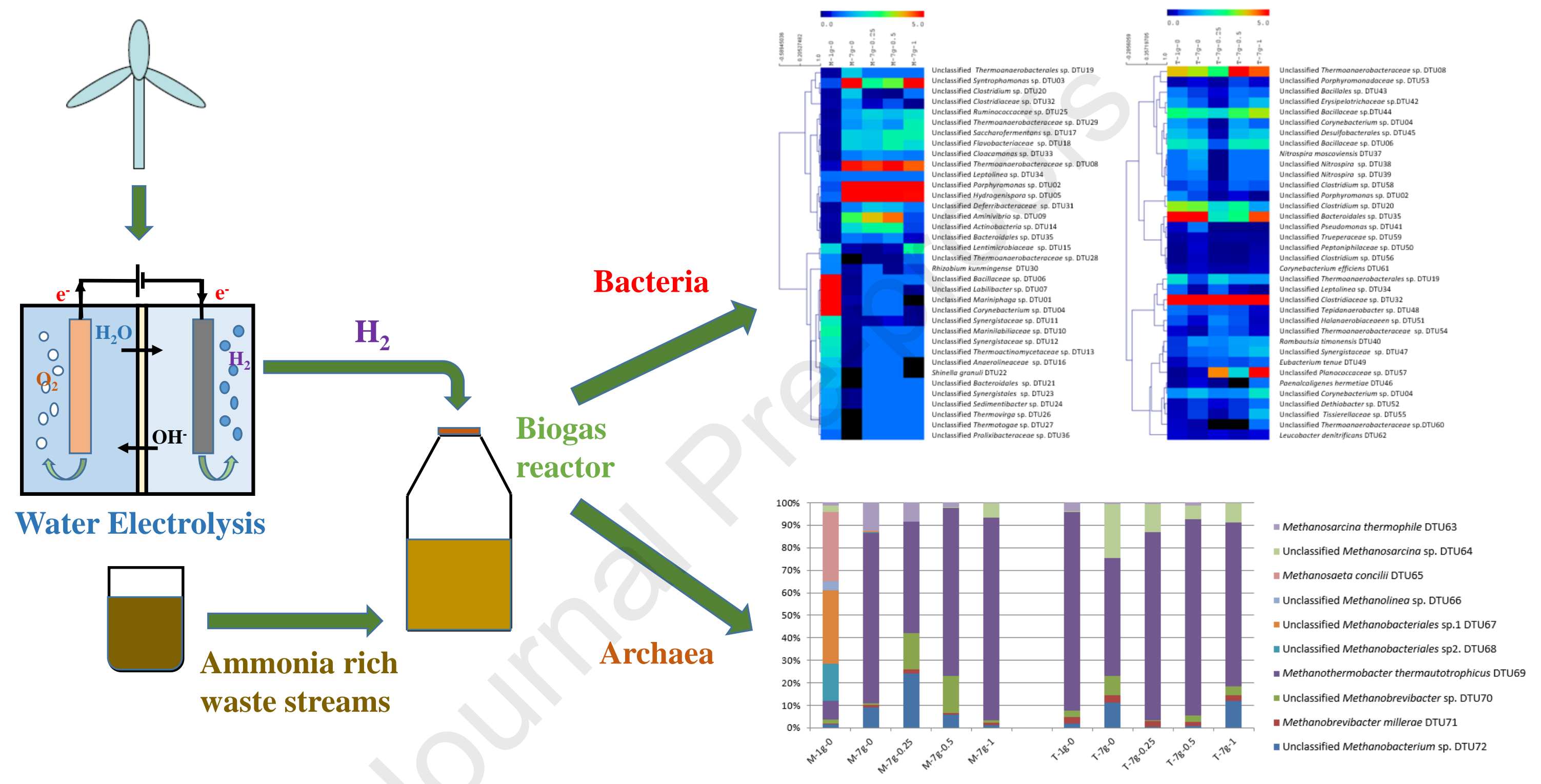

